\title{
Penetration in vitro of zona-free hamster eggs by ejaculated boar spermatozoa
}

\author{
H. Imai, K. Niwa and A. Iritani \\ Department of Animal Science, College of Agriculture, Kyoto University, Kyoto, Japan 606
}

The incorporation and fusion of capacitated, but not uncapacitated, spermatozoa with zona-free eggs in vitro have been reported for the hamster (Yanagimachi \& Noda, 1970), rat (Niwa \& Chang, 1975 ) and mouse (Wolf, Inoue \& Stark, 1976). A requirement of sperm capacitation for penetration of zona-free hamster eggs by spermatozoa of the guinea-pig (Yanagimachi, 1972), mouse (Hanada \& Chang, 1972), rat (Hanada \& Chang, 1976) and man (Yanagimachi, Yanagimachi \& Rogers, 1976) has also been reported. It has been suggested therefore that zona-free hamster eggs, and possibly the eggs of other laboratory animals, may be used as a model to evaluate the fertilizing capacity of the spermatozoa of different species (Yanagimachi, 1972; Yanagimachi et al., 1976). The present investigation was of the ability of boar spermatozoa to penetrate zona-free hamster eggs.

The medium used for manipulation of gametes was a modified Krebs-Ringer bicarbonate (KRB) solution as prepared for the fertilization of rat eggs in vitro (Toyoda \& Chang, 1974). Whole semen was collected from a Landrace boar and the colloidal fraction was removed by filtering through double gauze. Ten $\mathrm{ml}$ of the semen were washed twice with the medium by centrifugation at $500 \mathrm{~g}$ for $10 \mathrm{~min}$. The sediment containing the spermatozoa was resuspended in about $2 \mathrm{ml} \mathrm{KRB}$ medium. A portion (about $0.5 \mathrm{ml}$ ) of the sperm suspension was preincubated at $37^{\circ} \mathrm{C}$ for $6.5-7 \mathrm{~h}$ in a $\mathrm{CO}_{2}$ incubator $\left(5 \% \mathrm{CO}_{2}\right.$ in air). Each of another two portions of the sperm suspension, 0.1 and $0.3-0.5$ $\mathrm{ml}$, was introduced into the oviduct and/or uterine horn, respectively, of an oestrous sow or a maturing gilt (about 8-9 months old) immediately after removal at a local slaughterhouse (Iritani, Sato \& Nishikawa, 1975). The ovarian end of the oviduct and the cervical end of the uterus were ligated after the introduction of spermatozoa and the reproductive tract was kept for $4-10 \mathrm{~h}$ in $0.9 \% \mathrm{NaCl}$ solution at $37^{\circ} \mathrm{C}$. The spermatozoa recovered by flushing the reproductive tracts after incubation were washed again by centrifugation at $500 \mathrm{~g}$ for $10 \mathrm{~min}$. For insemination, spermatozoa $(50 \mu \mathrm{l}$ of the concentrated suspension from the tract flushings and $10 \mu \mathrm{l}$ from the sample preincubated in KRB) were introduced into each plastic culture dish $(35 \times 11 \mathrm{~mm})$ containing zona-free hamster eggs to give a concentration of $0.01-11 \cdot 1 \times 10^{6}$ spermatozoa $/ \mathrm{ml}$. The motility of spermatozoa decreased only slightly after incubation in KRB medium, but was lost or very poor when recovered from the reproductive tracts. These spermatozoa, however, always became motile after washing although the motility was not better than that of spermatozoa incubated in KRB.

Mature female golden hamsters were induced to superovulate (Yanagimachi \& Chang, 1964) and the eggs were recovered from the ampulla $15-17 \mathrm{~h}$ after injection of $\mathbf{H C G}$. The eggs were treated for 10-25 min in KRB medium containing 0.1\% hyaluronidase (Type I: Sigma Chemical Co.) but without bovine serum albumin. To dissolve the zona pellucida, the eggs were treated for $2-5 \mathrm{~min}$ with $0.1 \%$ bovine pancreatic trypsin (Boehringer-Mannheim Co.). After washing twice in the medium containing bovine serum albumin the zona-free eggs were introduced into $0.4 \mathrm{ml}$ medium covered with mineral oil in a culture dish.

The eggs were picked up, mounted in toto, fixed and stained (Chang, 1952) $7 \cdot 5-8 \cdot 5 \mathrm{~h}$ after exposure to boar spermatozoa and examined under a phase-contrast microscope. The presence of an enlarged sperm head(s) or sperm pronucleus(ei) in the vitellus and the corresponding sperm tail(s) was regarded as evidence of sperm penetration. The number of eggs which had resumed the second maturation division at various stages after sperm penetration was also recorded.

It can be seen from Table 1 that only one zona-free egg was penetrated after insemination with boar spermatozoa preincubated in a modified KRB solution, but that $10-36 \%$ of eggs were penetrated 
Table 1. Penetration of zona-free hamster eggs in vitro by ejaculated boar spermatozoa

\begin{tabular}{|c|c|c|c|c|c|c|c|}
\hline \multirow[b]{2}{*}{$\begin{array}{l}\text { Preincubation } \\
\text { condition }\end{array}$} & \multirow[b]{2}{*}{$\begin{array}{l}\text { Duration of } \\
\text { preincubation } \\
\text { (h) }\end{array}$} & \multirow{2}{*}{$\begin{array}{c}\text { Sperm } \\
\text { concentration } \\
\text { at } \\
\text { insemination } \\
\left(\times 10^{6} / \mathrm{ml}\right)\end{array}$} & \multirow[b]{2}{*}{$\begin{array}{c}\begin{array}{c}\text { No. of } \\
\text { eggs } \\
\text { examined* }\end{array}\end{array}$} & \multicolumn{3}{|c|}{ No. of eggs penetrated } & \multirow{2}{*}{$\begin{array}{c}\text { No. of } \\
\text { eggs } \\
\text { activated } \\
\text { no. } \\
\text { penetratec } \\
(\%)\end{array}$} \\
\hline & & & & Total & $\begin{array}{c}\text { With } \\
\text { enlarged } \\
\text { sperm head }\end{array}$ & $\begin{array}{c}\text { With male } \\
\text { and female } \\
\text { pronuclei }\end{array}$ & \\
\hline $\begin{array}{l}\text { Modified KRB } \\
\text { solution }\end{array}$ & $6 \cdot 5-7$ & $3 \cdot 2-4 \cdot 9$ & 53 & 1 & $\mathbf{0}$ & 1 & $1(100)$ \\
\hline $\begin{array}{l}\text { Uterus and oviduct } \\
\text { of maturing gilt } \dagger\end{array}$ & 7.5 & $0 \cdot 3$ & 14 & 5 & 1 & 4 & $4(80)$ \\
\hline $\begin{array}{l}\text { Uterus of } \\
\text { maturing gilt }\end{array}$ & $4-10$ & $0 \cdot 01-4 \cdot 9$ & 58 & 19 & 14 & 5 & $5(26)$ \\
\hline $\begin{array}{l}\text { Uterus of } \\
\text { oestrous sow }\end{array}$ & $4-6.5$ & $4 \cdot 0-11 \cdot 1$ & 43 & 5 & 3 & 2 & $3(60)$ \\
\hline $\begin{array}{l}\text { Oviduct of } \\
\text { maturing gilt }\end{array}$ & $4-10$ & $0.01-10.5$ & 65 & 15 & 15 & $\mathbf{0}$ & $2(13)$ \\
\hline $\begin{array}{l}\text { Oviduct of } \\
\text { oestrous sow }\end{array}$ & $6 \cdot 5$ & 6.9 & 31 & 3 & 3 & $\mathbf{0}$ & $0(0)$ \\
\hline
\end{tabular}

* The eggs were examined $7 \cdot 5-8 \cdot 5 \mathrm{~h}$ after insemination.

$\dagger$ Spermatozoa recovered from uterus and oviduct were mixed and used for insemination.

by spermatozoa preincubated in the pig reproductive tract. More eggs were penetrated when inseminated with spermatozoa preincubated (a) in the uterus $(24 / 101=24 \%)(\mathrm{Pl}$. 1, Figs $1-7)$ than in the oviduct $(18 / 96=19 \%)$ (Pl. 1, Figs 8 and 9$)$, and (b) in the uterus or oviduct of maturing gilts than of oestrous sows. In the penetrated eggs, various stages of enlargement of the sperm head (Pl. 1, Figs 1, 3, 4, 6, 8 and 9) and transformation of the enlarged sperm head into the male pronucleus containing many nucleoli (Pl. 1, Figs 6, 7, and 10) were observed. A very high proportion (36/48= $75 \%$ ) of penetrated eggs had only an enlarged sperm head $7 \cdot 5-8 \cdot 5 \mathrm{~h}$ after insemination. The proportion of eggs penetrated and with a sperm pronucleus was higher when inseminated with spermatozoa preincubated in the uterus $(29 \%)$ than in the oviduct $(0 \%)$. Activation of eggs to early anaphase of the second meiotic division (P1. 1, Figs 5 and 8) or formation of the second polar body occurred in 33

\section{EXPLANATION OF PLATE 1}

Zona-free hamster eggs incubated with boar spermatozoa and photographed under phase-contrast microscopy after being stained with Lacmoid.

Figs 1 and 2. An egg $8 \mathrm{~h}$ after insemination with boar spermatozoa preincubated for $6.5 \mathrm{~h}$ in the uterus of an oestrous sow, showing (Fig. 1) a sperm head with clear signs of swelling and (Fig. 2) the second meiotic metaphase spindle (unactivated). The arrow indicates the sperm tail. $\times 520$.

Fig. 3. An egg $8 \mathrm{~h}$ after insemination with boar spermatozoa preincubated for $6.5 \mathrm{~h}$ in an oestrous sow uterus. A sperm head (large arrow) and its corresponding sperm tail (small arrow) can be seen. $\times 520$.

Figs 4 and 5. An egg 7.5 h after insemination with boar spermatozoa preincubated for $4 \mathrm{~h}$ in the uterus of a maturing gilt, showing different stages of swelling of the sperm heads (large arrows in Fig. 4) and egg chromosomes which are possibly at early anaphase of the second meiotic division (Fig. 5). One of the penetrating sperm tails is visible (small arrow in Fig. 4). $\times 520$.

Figs 6 and 7. Polyspermic eggs $7.5 \mathrm{~h}$ after insemination with boar spermatozoa preincubated for $4 \mathrm{~h}$ in the uterus of a maturing gilt, showing two sperm pronuclei (SP), one of which is just starting to transform to pronucleus (arrow) (Fig. 6: $\times 520$ ) and three sperm pronuclei (SP) and one female pronucleus (FP) (Fig. 7: $\times 260$ ).

Figs 8 and 9. Eggs $7.5 \mathrm{~h}$ after insemination with boar spermatozoa preincubated for $10 \mathrm{~h}$ in the oviduct of a maturing gilt, showing egg chromosomes at early anaphase (Fig. 8) and metaphase (Fig. 9) of the second meiotic division. Large and small arrows indicate enlarged sperm heads and sperm tails, respectively. $\times 260$.

Fig. 10. An egg $8 \mathrm{~h}$ after insemination with boar spermatozoa which were preincubated for $7.5 \mathrm{~h}$ in the uterus and oviduct of a maturing gilt and mixed after recovering, showing a female pronucleus (FP), a sperm pronucleus (SP) with its corresponding sperm tail (arrow) and the second polar body (2P). $\times 260$. 
PLATE 1

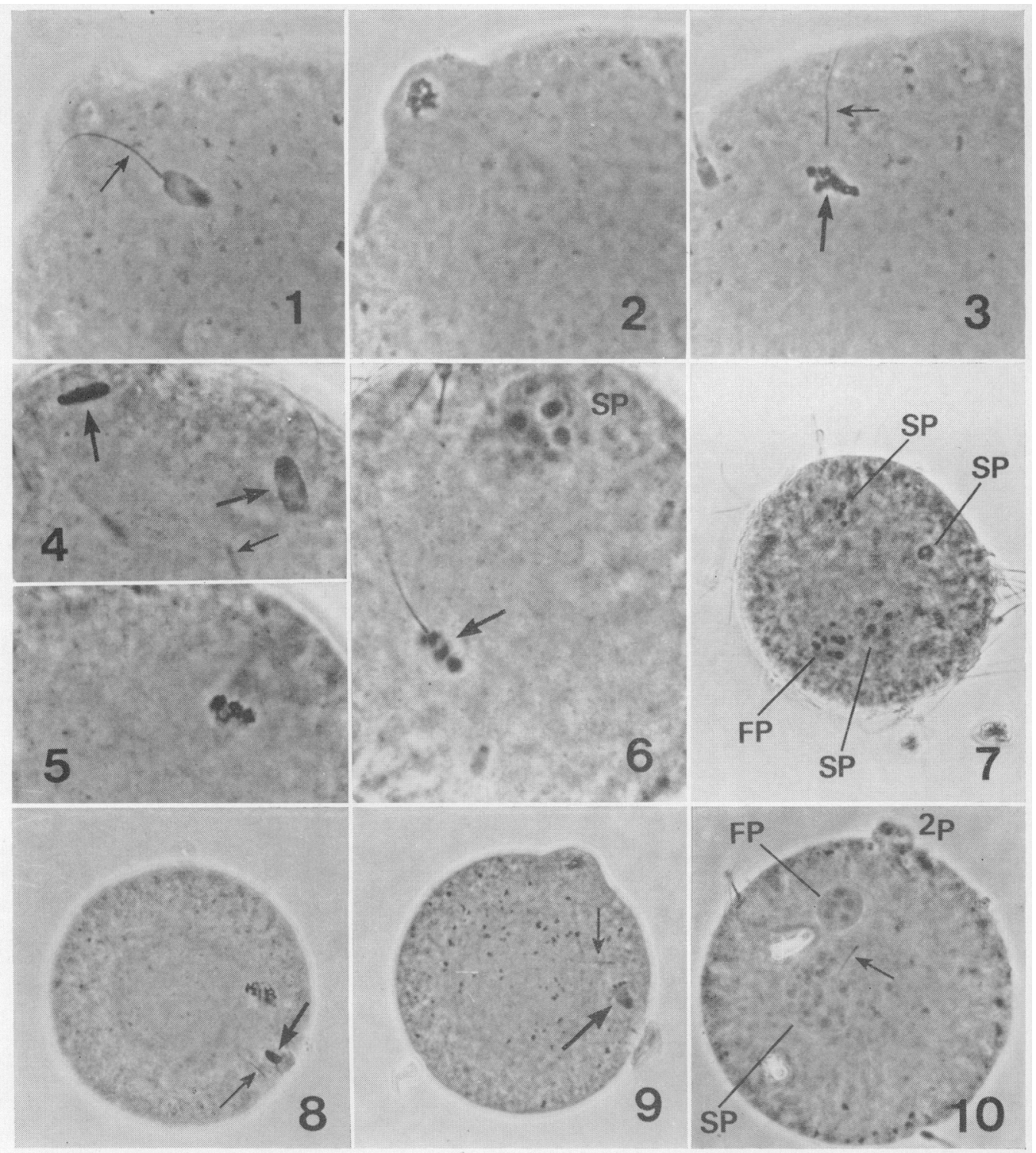


and $11 \%$ of those incubated with spermatozoa from the uterus and oviduct, respectively, showing that boar spermatozoa in the vitellus have little ability to activate hamster eggs. As shown in Table 1, the rates of penetration and of activation (Pl. 1, Fig. 10) of eggs cultured with spermatozoa from the uterus and oviduct of a maturing gilt were high.

From the results of this study it is clear that boar spermatozoa preincubated in a modified KRB solution penetrate zona-free hamster eggs with difficulty, but that they can do so after preincubation for several hours in the pig reproductive tract. This change in ability occurs more effectively in the reproductive tract of a maturing gilt than of an oestrous sow and in the uterus than in the oviduct. Although it is not clear whether these changes are concomitant with the capacitation of boar spermatozoa which is necessary for the penetration of intact pig eggs (Hunter \& Dziuk, 1968), the present results suggest that zona-free hamster eggs could be used as a substitute for pig eggs in the preliminary evaluation of the capacitation of boar spermatozoa.

The condition of the male pronucleus derived from boar spermatozoa in hamster eggs, particularly the large number of nucleoli (PI. 1, Figs 6, 7 and 10), was similar to that derived from hamster spermatozoa (Yanagimachi \& Chang, 1964) but dissimilar to that in pig eggs (Hunter, 1973), indicating the possible influence of vitelline factors on male pronuclear condition.

Some of this work was supported by a grant from the Ford Foundation (No. 7400404). A.I. thanks the Ministry of Education of Japan for a grant (No. 056120).

\section{References}

Chang, M.C. (1952) Fertilizability of rabbit ova and the effect of temperature in vitro on their subsequent fertilization and activation in vivo. J. exp. Zool. 121, 351-382.

Hanada, A. \& Chang, M.C. (1972) Penetration of zona-free eggs by spermatozoa of different species. Biol. Reprod. 6, 300-309.

Hanada, A. \& Chang, M.C. (1976) Penetration of hamster and rabbit zona-free eggs by rat and mouse spermatozoa with special reference to sperm capacitation. J. Reprod. Fert. 46, 239-241.

HunTer, R.H.F. (1973) Polyspermic fertilization in pigs after tubal deposition of excessive numbers of spermatozoa. J. exp. Zool. 183, 57-64.

HunTeR, R.H.F. \& DzIUK, P.J. (1968) Sperm penetration of pig eggs in relation to timing of ovulation and insemination. J. Reprod. Fert. 15, 199-208.

Iritani, A., Sato, E. \& Nishikawa, Y. (1975) The fertilization of pig follicular oocytes in vitro with capacitated spermatozoa. Jap. J. Fert. Steril. 20, $404-409$.

Niwa, K. \& Chang, M.C. (1975) Requirement of capacitation for sperm penetration of zona-free rat eggs. J. Reprod. Fert. 44, 305-308.
Toyoda, Y. \& Chang, M.C. (1974) Fertilization of rat eggs in vitro by epididymal spermatozoa and the development of such eggs following transfer. $J$. Reprod. Fert. 36, 9-22.

Wolf, D.P., Inoue, M. \& Stark, R.A. (1976) Penetration of zona-free mouse ova. Biol. Reprod. 15, 213-221.

Yanagimachi, R. (1972) Penetration of guinea-pig spermatozoa into hamster eggs in vitro. $J$. Reprod. Fert. 28, 477-480.

Yanagimachi, R. \& Chang, M.C. (1964) In vitro fertilization of golden hamster ova. J. exp. Zool. 156, 361-376.

YANAGIMACHI, R. \& NoDA, Y.D. (1970) Physiological changes in the post-nuclear cap region of mammalian spermatozoa: a necessary preliminary to membrane fusion between sperm and egg cells. $J$. Ultrastruct. Res. 31, 486-493.

YANAGIMACHI, R., YaNAGIMACHI, H. \& Rogers, B.J. (1976) The use of zona-free animal ova as a testsystem for the assessment of the fertilizing capacity of human spermatozoa. Biol. Reprod. 15, 471-476.

Received 13 April 1977 